\title{
Bruno Messerli (1931-2019)
}

\author{
PAGES Co-Director 1996-2001
}

\author{
Ray Bradley ${ }^{1}$, M. Grosjean², T.F. Stocker ${ }^{3}$ and H. Wanner ${ }^{2}$
}

After a long illness, Bruno Messerli passed away during a clear winter night in February 2019, surrounded by his wife Béatrice and his whole family. Bruno was an outstanding scientist, colleague and friend, full of enthusiasm, ideas and congeniality, and always ready to take the lead. We will miss him dearly.

After studying geography, geology and history and completing his doctoral thesis on the geomorphology of the Sierra Nevada in Andalusia, Spain, Bruno began his career with an impressive habilitation thesis on the Pleistocene glaciation of mountain ranges around the Mediterranean. This was the start of Bruno's broad and fruitful fieldwork in high-altitude mountains - in Africa (the Tassili, Tibesti, Aïr and Hoggar mountains in the Sahara, Semien mountains and Mount Kenya in East Africa), the arid Andes of South America and the Himalayas. For decades, his scientific work was driven by the question of whether or not the highest mountains in the most arid zones of the world were glaciated during the Last Glacial Maximum, or if the lack of moisture prevented widespread glaciation, despite extremely low temperatures. He investigated how glaciation in the mountains related to paleolakes and water resources in the nearby lowlands.

Bruno was a real mountaineer who loved the mountains and their people. Bruno's brilliant research work is characterized by his broad view of climate dynamics and climate history, with all its ecological consequences. In the spirit of his early mentor Carl Troll, he was able to outline an impressive picture of the long-term dynamics of the mountain climate system and its influence on geomorphological processes and natural resources, such as water, soil and vegetation. His contributions to studies of mountain hazards and highland-lowland interaction were seminal for many of his young colleagues. Together with his friend Hans Oeschger, Bruno was fascinated by new research methods such as radiocarbon dating, which he readily utilized to advance his research.

With his relentless enthusiasm, Bruno was a continuous generator of ideas and new projects. Parallel to his efforts in high-mountain research he initialized two research programs on regional and urban climate in the region and city of Bern, Switzerland, and supported research on Little Ice Age fluctuations in the Alps. He never hesitated to fight for mountain protection and development, always recalling the significance of the mountain landscape as a key resource for people living in it. He was proud to be one of the initiators and "fathers" of the Mountain Agenda in the

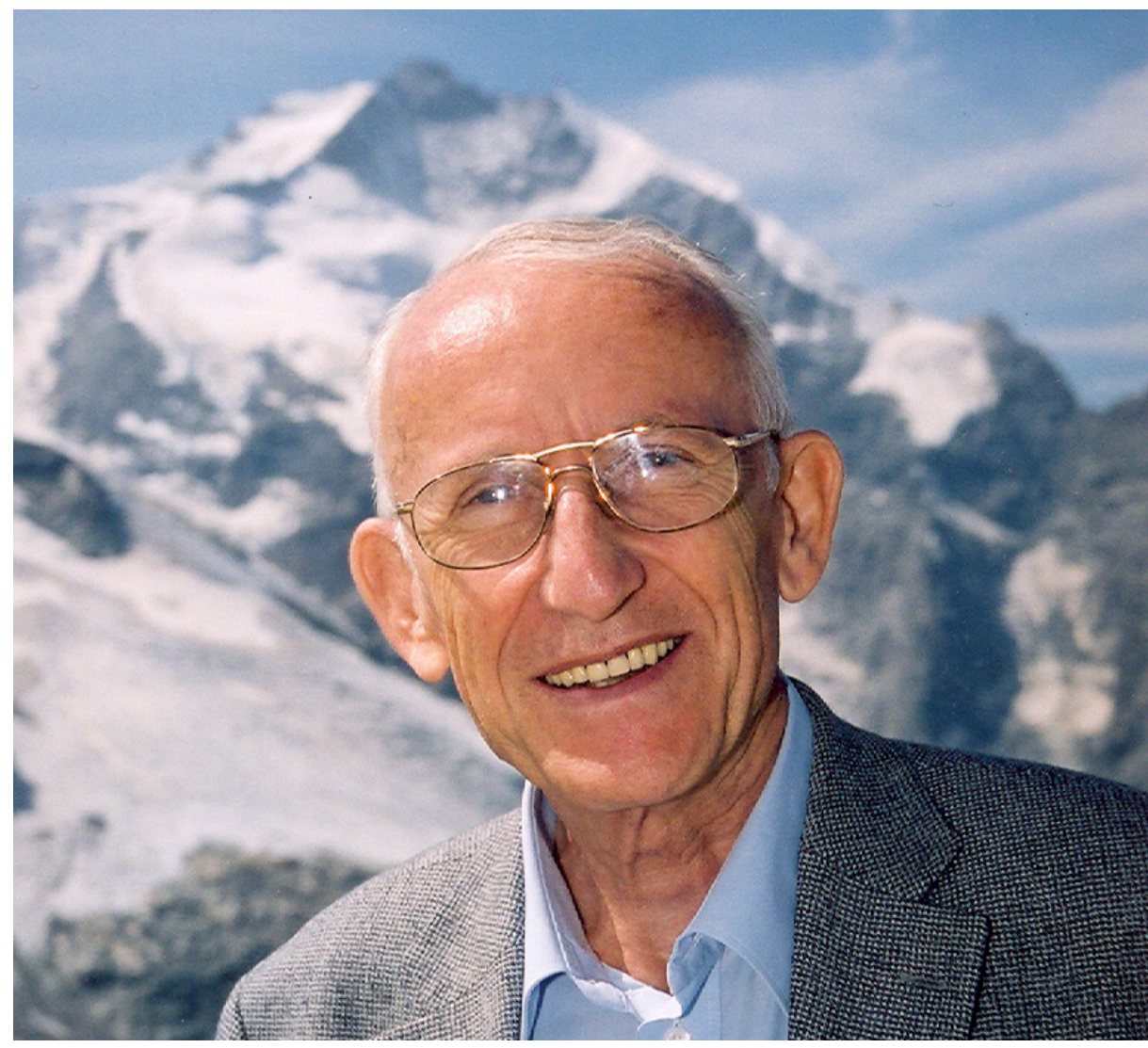

1992 Rio Declaration on Environment and Development (Chapter 13 in Agenda 21: "Managing Fragile Ecosystems: Sustainable Mountain Development", un-documents. net/a21-13.htm). He was a co-founder of the International Centre for Integrated Mountain Development (ICIMOD) in Nepal and of the Mountain Research Initiative, based in Switzerland. Bruno also enjoyed a long collaboration with the Food and Agriculture Organization of the United Nations, which acts as a task manager of the Mountain Agenda. His contribution to mountain research has thus had a broad and long-lasting impact.

Bruno was also an active and talented academic leader. He was professor of physical and regional geography at the University of Bern from 1969 to 1996 and acted as director of the Institute of Geography from 1978 to 1983 . From 1986 to 1987 he served as Rector of the University of Bern. Bruno was very happy when the Institute of Geography formed a new division focusing on sustainability in mountain areas of the world, now the Centre for Development and Environment. He also acted as President of the International Geographical Union from 1996 to 2000. Just three years after Hans Oeschger founded PAGES, Bruno joined the team, acting as co-director from 1996 to 2001 . He was excited by the spirit of the
PAGES team, in part because mountain climate research, historical climatology and the reconstruction of past climate based on natural archives and documentary data were some of his passions.

It is no surprise that Bruno received many prizes and honors, including honorary doctorates from the University of Innsbruck, Austria, and Free University of Berlin, Germany, the Prix Vautrin Lud, and he even shared the prestigious Marcel Benoist Prize with Hans Oeschger and Werner Stumm.

The international science community mourns an inspiring leader and scientist, a true giant of mountain research, but above all we have lost a dear friend. We all express our deep condolences to Bruno's family, and especially to his wife Béatrice, who was his active and charming partner, accompanying him on many trips around the world, both as a supporter and as a scientific advisor.

\section{AFFILIATIONS}

${ }^{1}$ Department of Geosciences, University of Massachusetts, Amherst, USA

2Oeschger Centre for Climate Change Research and Institute of Geography, University of Bern, Switzerland

${ }^{3}$ Oeschger Centre for Climate Change Research and

Physics Institute, University of Bern, Switzerland 